\title{
Esquistossomose Aguda, de Caráter Episódico, na Ilha de Itamaracá, Estado de Pernambuco
}

* Centro de Pesquisas Aggeu Magalhães/Fiocruz, Av. Moraes Rego s/n ${ }^{\circ}$, Campus da UFPE, Cidade Universitária, 50730 - Recife - PE

**Laboratório de Imuno-Patologia Keizo Asami/Lika.
Felipe Gonçalves*

Amaury Coutinho*

Walfrido Santana**

Constança Simões Barbosa*

Quatro casos agudos de infecção por Schistosoma mansoni foram diagnosticados, no mês de maio de 1990 , pelos Drs. Amaury Coutinho e Ana Lúcia Domingues (Hospital das Clínicas - UFPE), em pacientes que, presumivelmente, se infectaram em área próxima ao Forte Orange, sul da ilha de Itamaracá, distante cerca de $42 \mathrm{~km}$ da cidade do Recife.

Os quatro casos ocorreram na mesma família, mesmo dia e ocasião, no momento em que desceram do veículo (por motivo de pane no mesmo) e tiveram contato direto com água de chuva acumulada sobre extensa área de aterro em loteamento residencial de classe média/alta.

Os casos eram clinicamente sugestivos de infecção aguda por esquistossomose, e os exames hematológicos, sorológicos e parasitológicos de fezes confirmaram o diagnóstico.

Na posse das informações e dados acima relatados, uma equipe de pesquisadores deste Centro deslocou-se para o local, onde mapearam a área, identificando 12 focos ativos de transmissão. A população de caramujos era abundante e o único vetor encontrado foi $B$. glabrata.

No periodo de julho a agosto, em quatro coletas realizadas, foram capturados 7.217 caramujos dos quais $1.419(19,7 \%)$ estavam eliminando cercárias de $S$. mansoni.

Em área próxima ao sítio de transmissão de $B$. glabrata foi encontrado um pequeno criadouro de $B$. straminea, no qual foram coletados 290 espécimens que se mostraram negativos à infecção por $S$. mansoni.

A grande quantidade de $B$. glabrata encontrada nesses focos temporários, formados pelas chuvas, pode ser explicada pelo fato de que existem na localidade pequenas lagoas perenes, criadouros naturais de B. glabrata, que, ao transbordarem, na época chuvosa, distribuem os caramujos por toda a área, permitindo, assim, a sua proliferação. 
Vale assinalar que os quatro casos aqui descritos são claramente atribuídos a condições episódicas da infecção esquistossomótica.

A fonte de infecção pode ser atribuída à presença, no local, de trabalhadores da construção civil, oriundos de zona endêmica do estado (zona da mata). Essa sugestão é reforçada pelo fato de que, no mês de dezembro de 1990 , estação seca, quando a equipe ainda coletava caramujos nas lagoas perenes, podiam-se ver fezes humanas depositadas ao redor das lagoas. Nessa ocasião, foram coletados 178 caramujos $B$. glabrata que apresentaram taxa de infecção de $86,5 \%$.

Embora infreqüentes, casos semelhantes a este têm ocorrido em outras situações, em áreas endêmicas do país.

No que se refere especificamente a este trabalho, enfatiza-se o fato de que esses casos esporádicos possam se tornar freqüentes, todas as vezes que a localidade seja inundada no período chuvoso (maio a agosto).

Estudos continuam sendo realizados na área, para melhor caracterizar os padrōes epidemiológicos de transmissibilidade da infecção, que parece reger-se de caráter sazonal. 